\title{
Occurrence, Molecular Characterization and Physiological Study of Broccoli Infected with Turnip mosaic virus (TuMV) in Arunachal Pradesh, India
}

\author{
Raghuveer Singh $^{1 *}$, Amrita Banerjee ${ }^{2}$, Susheel Kumar Sharma ${ }^{3}$ and Valenta Kangjam ${ }^{4}$ \\ ${ }^{1}$ ICAR Research Complex for NEH Region, Arunachal Pradesh Centre, Basar-791101, India \\ ${ }^{2}$ ICAR-NRRI, Central Rainfed Upland Rice Research Station, \\ Hazaribag (Jharkhand)-825301, India \\ ${ }^{3}$ ICAR Research Complex for NEH Region, Manipur Centre, \\ Lamphelpat (Imphal)-795004, India \\ ${ }^{4}$ Department of Plant Pathology, SASRD, Nagaland University, Medziphema-797106, India \\ *Corresponding author
}

Keywords

TuMV,

Transmission

electron

microscopy, DAS-

ELISA, RT-PCR,

Phylogeny

\section{Article Info}

Accepted:

10 July 2020

Available Online:

10 August 2020

\begin{abstract}
A B S T R A C T
Broccoli (Brassica oleracea var. italica) is an important part of diet in India. Turnip mosaic virus (TuMV), member of the genus Potyvirus, is the most important virus of commercially grown broccoli in many Asian countries. Symptoms based survey of different backyard vegetable gardens during rabi season of 2015-16, revealed that the mean disease incidence of TuMV was 36.21 per cent. The occurrence of TuMV in Broccoli was confirmed by symptomatology, transmission electron microscopy (flexuous filamentous particles of $800 \times 12 \mathrm{~nm}$ ), DAS-ELISA, RT-PCR and partial characterization of cytoplasmic inclusion (CI) protein and coat protein $(\mathrm{CP})$ domains. Phylogenetic analysis of the partial CP sequences of the new TuMV isolate (AR-Brc; KP876504) revealed their closest relationship with the members of the World-B genogroup of TuMV. Significant physiological changes were observed in diseased leaves in terms of chlorophyll, total sugar, reducing sugar, total phenol and total proteins. There was significant decrease in chlorophyll contents; chlorophyll-a (48.75\%), chlorophyll-b (42.86\%) and total chlorophyll (47.77\%). Total protein content significantly increased in case of severe symptoms $(22.55 \%)$ followed by mild symptoms (19.61\%). There was a significant increase in the total sugar content in mild symptom $(60 \%)$ followed by severe symptoms (20\%). Significant increase in the reducing sugar content was also observed in mild symptoms $(5.88 \%)$ whereas it decreased in severe symptoms $(11.76 \%)$. Similarly, total phenol content also significantly increased in mild type $(9.09 \%)$ whereas it decreased in severe symptoms $(13.63 \%)$.
\end{abstract}

\section{Introduction}

Broccoli (Brassica oleracea var. italica) is an edible green plant in the cabbage family whose large flowering head and stalk is eaten as a vegetable in India. In Arunachal Pradesh this crop is usually grown in rabi season. Despite the ability of broccoli to grow under a 
very wide range of climatic and soil conditions, problems such as diseases and insect-pests reduce its yield significantly. Among the diseases, Turnip mosaic virus (TuMV) is one of the most economically important plant virus worldwide having wide host range over 300 species. In India, reports on TuMV in broccoli are very few and it may be considered as an emerging threat for its cultivation (Singh et al., 2015 and Singh et $a l$. , 2018). Keeping this in view, this paper highlights the potential of the disease, physiological study, molecular characterization, transmission electron microscopy of broccoli infected with TuMV.

\section{Materials and Methods}

\section{Disease survey}

This study was carried out at ICAR research complex for NEH Region, Arunachal Pradesh Center, Basar, India. It lies in between $27^{\circ} 59^{\prime}$ $\mathrm{N}$ latitudes, $94^{\circ} 40^{\prime} \mathrm{E}$ longitudes with $650 \mathrm{~m}$ altitude from MSL. During 2015-16, intensive surveys were conducted for the presence of the TuMv disease in the farmers' vegetable fields. The incidence of the TuMV was recorded through random sampling from 10 vegetable fields. The disease incidence was based on the visual observation of the characteristic symptoms. Ten healthy and diseased leaves were randomly collected from each location and further brought to the laboratory for the estimation of yield loss.

\section{Transmission electron microscopy (EM)}

The symptomatic leaf samples were collected from field and examined under EM following the leaf dip method. The preparations were negatively stained using $2 \%$ aqueous uranyl acetate $(\mathrm{pH} 4.5)$. The grid was placed on a drop of extract from petiole of leaves. After 1 min the grid was washed with 10 drops of distilled water and stained with $2 \%$ uranyl acetate. Immediately after drying the grid was examined under EM.

\section{Double antibody sandwich (DAS)-ELISA}

The symptomatic and non-symptomatic leaf samples were collected from fields. They were tested for the presence of TuMV by DAS-ELISA protocols (Clark and Adams, 1977).

\section{Molecular characterization}

The symptomatic and non-symptomatic leaf samples were collected from the farmers' fields. Total RNA extracts (RNeasy Plant Mini Kit, Qiagen Inc, Valencia, CA) from symptomatic, as well as non-symptomatic samples were subjected to reverse transcription (RT)-PCR assays using OneStep RT-PCR kit (Qiagen Inc, Valencia, CA), one set of Potyvirus-specific degenerate primer (CIF/CIRev) targeting the cylindrical inclusion $(\mathrm{CI})$ protein domain and coat protein $(\mathrm{CP})$ specific primer (TuMV $\mathrm{CP}$ F/TuMV CP-R). The RT-PCR amplicons were gel purified (GeneJET, Fermentas, India) and each fragment was sequenced bidirectionally (Biolink, New Delhi, India).

\section{Physiological changes in broccoli infected with TuMV}

For estimation of chlorophyll, healthy and diseased leaves were taken randomly from the base of plant. The leaves were washed with distilled water and the water was soaked by filter paper. Then, fresh leaf samples were weighed accurately $(50 \mathrm{mg}$ ) on an analytical balance and chlorophyll was extracted by a non macerated method. The chlorophyll extract was transferred to a cuvette and the absorbance was read in a spectrophotometer (Genesys, $10 \mathrm{uv}$ ) at $645 \mathrm{~nm}$ and $663 \mathrm{~nm}$ against DMSO blank. Chlorophyll-a, b and total were calculated by using following formula: 
Chlorophyll-a (mg/g tissue $)=[12.7($ D 663) $2.69(\mathrm{D} 645)] \times \mathrm{V} / 1000 \times \mathrm{W}$

Chlorophyll-b (mg/g tissue $)=[22.9(\mathrm{D}$ 645) $4.68(\mathrm{D} 663)] \times \mathrm{V} / 1000 \times \mathrm{W}$

Total Chlorophyll $(\mathrm{mg} / \mathrm{g}$ tissue $)=[20.2(\mathrm{D}$ $645)+8.02(\mathrm{D} 663)] \times \mathrm{V} / 1000 \times \mathrm{W}$

Where: $\mathrm{D}=$ Optical density at respective $\mathrm{nm}$, $\mathrm{V}=$ Final volume of chlorophyll extract (i.e. $10 \mathrm{ml}), \mathrm{W}=$ Fresh weight of the tissue extracted (i.e. $50 \mathrm{mg}$ ).

The total sugar content was estimated by Hedge and Hofreiter method and reducing sugar by Somogyi method.

For estimation of total phenol and total protein, Folin and Ciocalteu and Lowry methods were used respectively.

\section{Results and Discussion}

The first symptoms of the disease were noticed during the $1^{\text {st }}$ week of December, 2015 which prevailed upto March month. Symptoms of the disease were mosaic, mottling, downward curling of leaf lamina, twisting and chlorosis of leaves (Fig.1). Severally affected plants showed stunted growth and reduced size of leaves which appeared thickened leathery and brittle in texture.

Symptoms based survey of different backyard vegetable gardens during rabi season of 201516 revealed that the mean disease incidence of TuMV was 36.21 per cent. Similarly, Devi et al., (2004) reported disease incidence from 63.25 to $90.5 \%$ in Manipur, India.

In the farmers' fields the maximum disease incidence was recorded in broad leaved mustard (63.67\%) in Basar, Arunachal Pradesh (Singh et al., 2018). Therefore, it may emerge as a potential threat for broccoli cultivation in Arunachal Pradesh, India.

The symptomatic leaf samples when examined under electron microscope revealed the presence of flexuous filamentous virus particle of $800 \times 12 \mathrm{~nm}$ (Fig. 2), indicating the possibility of a Potyvirus. Haq et al., (2008) and Singh et al., (2018) also reported to have similar particle morphology of TuMV infecting broad leaved mustard.

DAS-ELISA using poty-group specific antisera confirmed the association of Potyvirus and $36 \%$ of tested samples were positive with infected sample showing absorbance values of greater than 2.5 folds compared to healthy samples. Similarly, Singh et al., (2018) also confirmed in broad leaved mustard.

Transmission EM and DAS-ELISA observation indicated the possibility of Potyvirus infection. Therefore, attempt was made to identify and characterize the virus species at molecular level by applying RTPCR.

The symptomatic leaf sample showed virus specific amplification of $\sim 700$ bp (Potyvirus specific degenerate primer, $\mathrm{ClF} / \mathrm{CIRev}$ ) of cylindrical inclusion (CI) protein domain (Fig. 3).

The RT-PCR amplicon from the sample was gel purified and fragment was sequenced bidirectionally. The partial sequence was assembled and submitted in National Center for Biotechnology Information (NCBI) GenBank (KP876501; AR-Brc). A total of 33 sequences were aligned using Clustal W algorithm of MEGA6 and the phylogenetic tree was constructed on the matrices of aligned sequences with 1000 bootstrap replicates following neighbor-joining phylogeny of MEGA6. 
Table.1 Effect of TuMV infection on total sugar, reducing sugar, total phenol and total protein contents in Broccoli (var. Green magic) at 60 DAS

\begin{tabular}{|c|c|c|c|c|c|c|c|c|}
\hline \multirow{2}{*}{$\begin{array}{l}\text { Intensity of } \\
\text { Symptoms }\end{array}$} & \multicolumn{2}{|c|}{ Total sugar } & \multicolumn{2}{|c|}{ Reducing sugar } & \multicolumn{2}{|c|}{ Total phenol } & \multicolumn{2}{|c|}{ Total protein } \\
\hline & $\begin{array}{c}\text { Content } \\
\text { (mg/g fresh weight) }\end{array}$ & $\begin{array}{c}\% \text { increase }(+) \text { or } \\
\text { decrease }(-)\end{array}$ & $\begin{array}{l}\text { Content } \\
\text { (mg/g fresh } \\
\text { weight) }\end{array}$ & $\begin{array}{l}\% \text { increase (+) } \\
\text { or decrease (-) }\end{array}$ & $\begin{array}{l}\text { Content } \\
\text { (mg/g fresh } \\
\text { weight) }\end{array}$ & $\begin{array}{l}\% \text { increase }(+) \\
\text { or decrease }(-)\end{array}$ & $\begin{array}{l}\text { Content } \\
\text { (mg/g fresh } \\
\text { weight) }\end{array}$ & $\begin{array}{l}\% \text { increase }(+) \\
\text { or decrease (-) }\end{array}$ \\
\hline \multicolumn{9}{|l|}{ Mild symptom } \\
\hline Sample-1 & 0.09 & & 0.16 & & 0.25 & & 1.16 & \\
\hline Sample-2 & 0.08 & & 0.19 & & 0.24 & & 1.19 & \\
\hline Sample-3 & 0.09 & & 0.22 & & 0.25 & & 1.27 & \\
\hline Sample-4 & 0.08 & & 0.16 & & 0.23 & & 1.26 & \\
\hline Mean & 0.08 & +60.00 & 0.18 & +5.88 & 0.24 & +9.09 & 1.22 & +19.61 \\
\hline \multicolumn{9}{|l|}{ Severe symptom } \\
\hline Sample-1 & 0.06 & & 0.14 & & 0.15 & & 1.18 & \\
\hline Sample-2 & 0.06 & & 0.16 & & 0.17 & & 1.22 & \\
\hline Sample-3 & 0.07 & & 0.14 & & 0.25 & & 1.13 & \\
\hline Sample-4 & 0.06 & & 0.16 & & 0.19 & & 1.48 & \\
\hline Mean & 0.06 & +20.00 & 0.15 & -11.76 & 0.19 & -13.63 & 1.25 & +22.55 \\
\hline \multicolumn{9}{|l|}{ Healthy leaf } \\
\hline Sample-1 & 0.05 & & 0.16 & & 0.18 & & 1.03 & \\
\hline Sample-2 & 0.06 & & 0.16 & & 0.28 & & 1.07 & \\
\hline Sample-3 & 0.05 & & 0.22 & & 0.23 & & 1.18 & \\
\hline Sample-4 & 0.06 & & 0.14 & & 0.20 & & 0.79 & \\
\hline Mean & 0.05 & - & 0.17 & - & 0.22 & - & 1.02 & - \\
\hline
\end{tabular}


Table.2 Effect of TuMV infection on chlorophyll contents, leaf weight and their disease incidence in Broccoli (var. Green magic) at 60 DAS

\begin{tabular}{|c|c|c|c|c|c|c|c|c|c|c|c|c|c|c|c|}
\hline \multirow{3}{*}{$\begin{array}{c}\text { Sampl } \\
\text { e }\end{array}$} & \multicolumn{2}{|c|}{$\begin{array}{c}\text { Leaf weight } \\
\text { (g) }\end{array}$} & \multirow{3}{*}{$\begin{array}{c}\text { Weight } \\
\text { loss of } \\
\text { leaf } \\
(\%)\end{array}$} & \multicolumn{9}{|c|}{ Chlorophyll contents (mg/g fresh weight) } & \multicolumn{3}{|c|}{ Disease Incidence } \\
\hline & \multirow{2}{*}{$\mathbf{H}$} & \multirow{2}{*}{$\mathbf{D}$} & & \multicolumn{2}{|c|}{ Chlorophyll-a } & \multirow{2}{*}{$\begin{array}{c}\text { Percent } \\
\text { decrease } \\
(\%)\end{array}$} & \multicolumn{2}{|c|}{ Chlorophyll-b } & \multirow{2}{*}{$\begin{array}{c}\text { Percent } \\
\text { decrease } \\
(\%)\end{array}$} & \multicolumn{2}{|c|}{ Total } & \multirow{2}{*}{$\begin{array}{c}\text { Percent } \\
\text { decrease } \\
(\%)\end{array}$} & \multirow{2}{*}{$\begin{array}{l}\text { Total } \\
\text { plant } \\
\text { (No.) }\end{array}$} & \multirow{2}{*}{$\begin{array}{c}\text { Infected } \\
\text { plant } \\
\text { (No.) }\end{array}$} & \multirow[t]{2}{*}{$\%$} \\
\hline & & & & $\mathbf{H}$ & D & & $\mathbf{H}$ & D & & $\mathbf{H}$ & D & & & & \\
\hline 1 & 18.89 & 07.31 & \multirow[t]{7}{*}{49.20} & 2.86 & 1.30 & \multirow[t]{7}{*}{48.75} & 0.02 & 0.34 & \multirow[t]{7}{*}{42.86} & 2.88 & 1.64 & \multirow[t]{7}{*}{47.77} & \multirow[t]{7}{*}{58} & \multirow[t]{7}{*}{21} & \multirow[t]{7}{*}{36.21} \\
\hline 2 & 17.55 & 08.95 & & 3.26 & 1.25 & & 0.30 & 0.45 & & 3.56 & 1.70 & & & & \\
\hline 3 & 14.61 & 07.82 & & 2.07 & 1.66 & & 1.65 & 0.27 & & 3.72 & 1.93 & & & & \\
\hline 4 & 09.75 & 08.47 & & 2.90 & 1.56 & & 0.63 & 0.25 & & 3.53 & 1.81 & & & & \\
\hline 5 & 13.43 & 06.85 & & 3.27 & 1.29 & & 0.30 & 0.34 & & 3.57 & 1.63 & & & & \\
\hline 6 & 15.32 & 06.07 & & 2.54 & 1.60 & & 0.46 & 0.27 & & 3.00 & 1.87 & & & & \\
\hline Mean & 14.92 & 07.58 & & 2.81 & 1.44 & & 0.56 & 0.32 & & 3.37 & 1.76 & & & & \\
\hline
\end{tabular}

Where is:

Percent decrease $(\%)=$ Mean chlorophyll ( $\mathrm{a}, \mathrm{b}$ and total) of healthy leaves - Mean chlorophyll ( $\mathrm{a}, \mathrm{b}$ and total) of diseased leaves / Mean chlorophyll (a, $\mathrm{b}$ and total) of healthy leaves x 100 .

$\mathrm{H}=$ Healthy \& $\mathrm{D}=$ Diseased.

Fig.1 View of a) healthy, b) mild and c) severe infected leaf of Broccoli (Var. Green Magic)

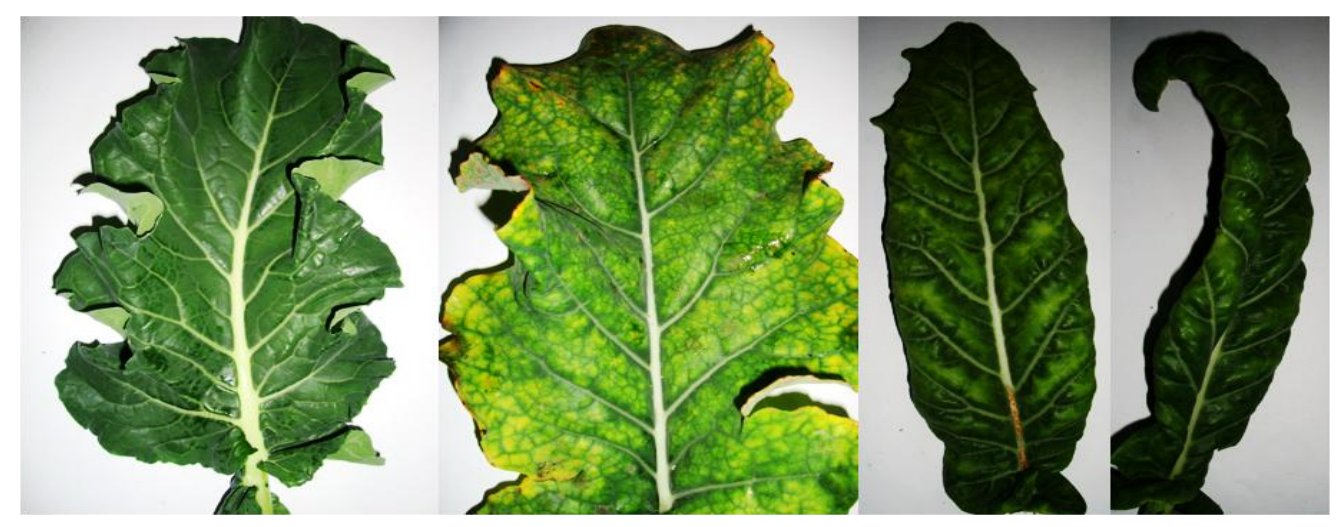


Fig.2 Transmission electron micrograph of flexuous filamentous Potyvirus particles in infected leaf tissue

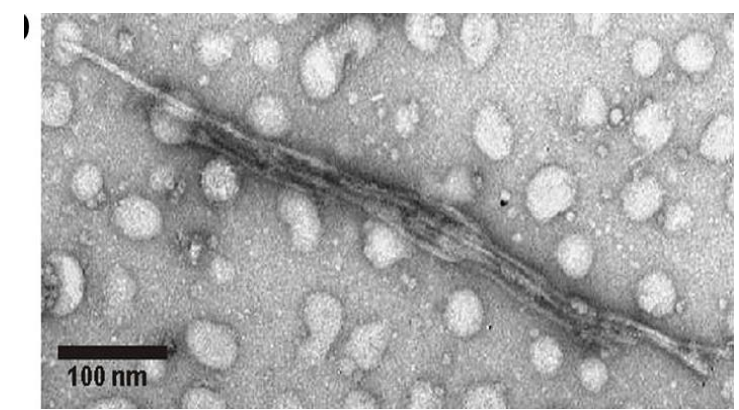

Fig.3 RT-PCR detection of Potyvirus using degenerate primer (CIF/CIRev) and revalidation of TuMV infection through RT-PCR using TuMV CP-F/TuMV CP-R specific primer; $\mathrm{M}=1 \mathrm{~kb}$ DNA ladder; lane 1-3 template from symptomatic; lane 4-6 template from non-symptomatic plants

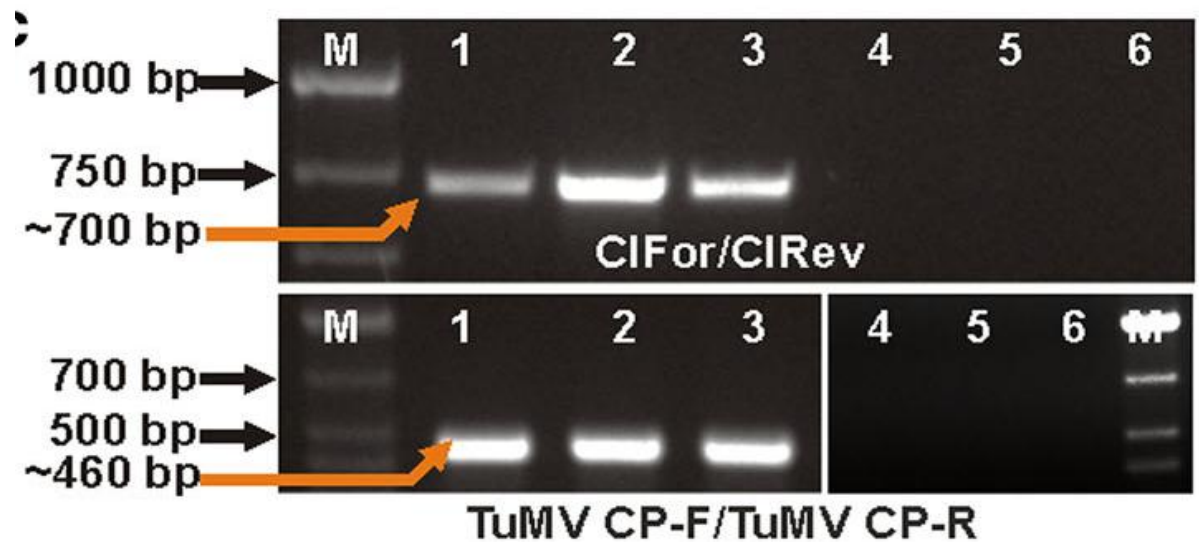

The initial BLAST analysis showed that the partial CI domain of the new isolate (KP876501; AR-Brc) shared 91-95\% nucleotide identity with previously reported TuMV isolates available in GenBank (KF246570). However, the maximum nucleotide identity of $95 \%$ was shared with TuMV isolate ZHI from China (KF246570). The corresponding protein identity was 98.9$99.5 \%$ with the same isolate (protein id AGX26124). Findings were revalidated by screening the same samples with TuMV coat protein (CP) specific primers (TuMV CPF/TuMV CP-R). Only the infected samples gave specific amplicon of $\sim 460 \mathrm{bp}$. Further, the direct sequencing of the eluted amplicons (368 bp) generated from TuMV CP specific primers (KP876504: AR-Brc) showed 100\% identity with previously reported TuMV isolates both at nucleotide and protein level. Thus, TUMV was identified as the causal agent of mosaic disease in broccoli. The partial CP sequence (KP876504) was compared with 33 TuMV isolates representing all genogroups of TuMV. Phylogenetic analysis of the partial CP sequences (AR-Brc; KP876504) of the TuMV isolate revealed their closest relationship with the members of the World-B genogroup of TuMV. 
The minimum amount of chlorophyll-a (1.44 $\mathrm{mg} / \mathrm{g}$ fresh tissue), chlorophyll-b $(0.32 \mathrm{mg} / \mathrm{g}$ fresh tissue) and total chlorophyll $(1.76 \mathrm{mg} / \mathrm{g}$ fresh tissue) were recorded in diseased leaves and the maximum amount of chlorophyll-a (2.81 $\mathrm{mg} / \mathrm{g}$ fresh tissue), chlorophyll-b (0.56 $\mathrm{mg} / \mathrm{g}$ fresh tissue) and total chlorophyll (3.37 $\mathrm{mg} / \mathrm{g}$ fresh tissue) was recorded in healthy leaves (Table 2). Most of the viral and bacterial infection leads to chlorosis (Guo et al., 2005 and Singh et al., 2018).

There was a significant increase in the total sugar and reducing sugar contents in mild symptom (60\% and $5.88 \%$, respectively) and then found significantly decreased reducing sugar in severe type of symptoms (Table 1). One of the metabolic functions of the sugars is the formation of phosphate esters which serve as substrate for respiration and release of energy. Due to retarded photosynthesis activity, less starch may have been synthesized in viral infected leaves. An enhanced rate of respiration was observed in pigeonpea leaves infected with pigeonpea sterility mosaic virus (Nambiar, 2006).

Similarly, total phenol content was also observed significantly increased in mild symptom $(9.09 \%)$ and then found decreased in severe type $(13.63 \%)$ of symptoms (Table 1). Reason for the decrease of phenol content in severe mottling type could be due to enhanced synthesis of viral components in the host cells competing with normal biosynthetic pathways (Wood, 2010).

Total protein content was also observed significantly increased in severe symptoms $(22.55 \%)$. This results shows that virus infection leads to increased total protein content due to accumulation of viral proteins (Singh et al., 2018).

Physiological and photosynthetic properties and growth of plants infected by virus have been shown negatively influenced by several researchers (Ryslava et al., 2008 and Funayama et al., 2010). It is often found that fitness of virus-infected plants was lower than that of healthy plants. The low productivity of infected plants has been probably due to physiological stress with low photosynthetic rate of chlorotic leaves. Actually decrease in photosynthetic rate of the infected leaves is often associated with development of the symptoms (Singh et al., 2018). The present findings supported the physiological changes observed in broccoli infected with TuMV.

\section{References}

Clark, M.F. and Adams, A.N. 1977. Characteristics of the microplate method of enzyme-linked immunosorbent assay for the detection of plant viruses. Journal of General Virology. 34: 475-483.

Devi, S.P., Bhat, A.I., Devi, L.R. and Das, M.L. 2004. Occurrence, transmission and genotype response of a filamentous virus associated with leaf mustard (Brassica juncea var. rugosa) in Manipur. Indian Phytopathology. 57: 488-493.

Funayama, S., Hikosaka, K. and Yahara, T. 2010. Effects of virus infection and growth irradiance on fitness components and photosynthetic properties of Eupatorium makinoi (Compositae). American Journal of Botany. 84: 823-829.

Guo, D.P., Guoa, Y.P., Zhaoa, J.P., Liua, H., Penga, Y., Wanga, Q.M., Chenb, J.S. and Raoc, G.Z. 2005. Photosynthetic rate and chlorophyll fluorescence in leaves of stem mustard (Brassica juncea var. tsatsai) after turnip mosaic virus infection. Plant Science. 168: 57-63.

Haq, Q.M.R., Srivastava, K.M., Raizada, R.K., Singh, B.P., Jain, R.K., Mishra, A. and Shukla, D.D. 2008. Biological, 
serological and coat protein properties of a strain of Turnip mosaic virus causing a mosaic disease of Brassica campestries and Brassica juncea in India. Journal of Phytopathology. 140: 55-64.

Nambiar, K.K.N. 2006. Studies on pigeonpea sterility mosaic disease. Madras, India: University of Madras. Ph.D. Thesis.

Ryslava, H., Muller, K., Semoradova, S., Synkova, H. and Cerovska, N. 2008. Photosynthesis and activity of phosphoenol pyruvate carboxylase in Nicotiana tabacum L. leaves infected by potato virus $\mathrm{A}$ and potato virus $\mathrm{Y}$. Photosynthetica. 41: 357-363.

Singh, R., Banerjee, A., Sharma, S.K., Bhagawati, R., Baruah, S. and Ngachan, S.V. 2015. First report of Turnip mosaic virus occurrence in cole crop (Brassica spp.) from Arunachal Pradesh, India. Virus Disease. 26: 211-213.

Singh, R., Banerjee, A., Sharma, S.K., Chandra, A., Baruah, S., Khatoon, A., Sen, A. and Shukla, K.K. 2018. Occurrence, molecular characterization, physiological study and yield loss assessment of Broad-leaved mustard (Brassica juncea var. rugosa) infected with Turnip mosaic virus in Arunachal Pradesh. Environment and Ecology. 36 (2): 489-494.

Wood, K.R. 2010. Pathophysiological alterations. In: Mandahar C.L. (ed). Plant Viruses II. CRC Press, Boca Raton. pp. 23-63.

\section{How to cite this article:}

Raghuveer Singh, Amrita Banerjee, Susheel Kumar Sharma and Valenta Kangjam. 2020. Occurrence, Molecular Characterization and Physiological Study of Broccoli Infected with Turnip mosaic virus (TuMV) in Arunachal Pradesh, India. Int.J.Curr.Microbiol.App.Sci. 9(08): 1035-1042. doi: https://doi.org/10.20546/ijcmas.2020.908.113 